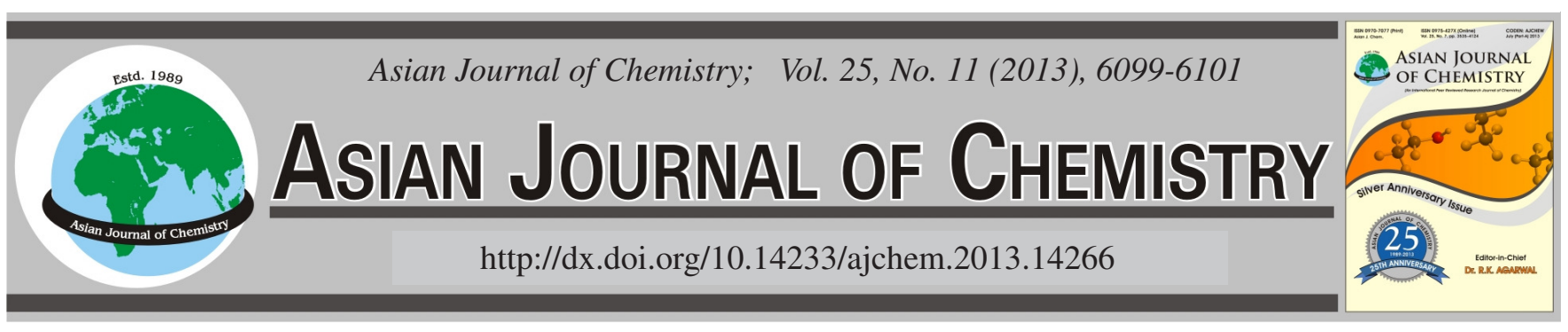

\title{
Influence of Auxins on Glucosinolate Biosynthesis in Hairy Root Cultures of Broccoli (Brassica oleracea var. italica)
}

\section{Haeng Hoon Kim ${ }^{1}$, Do Yeon Kwon ${ }^{2}$, Hanhong BaE ${ }^{3}$, Sun-Ju Kim ${ }^{4}$, Yeon BoK KIm², MD. Romid Uddin ${ }^{2}$ and SAng Un Park ${ }^{2, *}$}

${ }^{1}$ Department of Well-being Resources, Sunchon National University, 413 Jungangno, Suncheon, Jeollanam-do 540-742, Republic of Korea ${ }^{2}$ Department of Crop Science, Chungnam National University, 99 Daehak-ro, Yuseong-Gu, Daejeon 305-764, Republic of Korea ${ }^{3}$ School of Biotechnology, Yeungnam University, Gyeongsan 712-749, Republic of Korea

${ }^{4}$ Department of Bio-Environmental Chemistry Chungnam National University, 99 Daehak-ro, Yuseong-Gu, Daejeon 305-764, Republic of Korea

*Corresponding author: Fax: +82 42 8222631; Tel: +82 42 8215730; E-mail: supark@cnu.ac.kr

\begin{abstract}
One of the most significant health benefits of cruciferous vegetables results from the presence of biologically active compounds, glucosinolates. Broccoli (Brassica oleracea var. italica) is a nutritionally important crop grown all over the world. The primary purpose of this study was to evaluate the effect of auxins on glucosinolate biosynthesis in the hairy root of broccoli. Eight different glucosinolates, including glucoraphanin, gluconapin, 4-hydroxyglucobrassicin, glucoerucin, glucobrassicin, 4-methoxyglucobrassicin, gluconasturtiin and neoglucobrassicin, were identified by analysis of broccoli hairy root cultures. Low concentration of auxins $(0.1 \mathrm{mg} / \mathrm{L}) \mathrm{resulted}$ in the highest accumulation of glucosinolates. Treatment with higher concentrations resulted less accumulation of glucosinolates than treatment with $0.1 \mathrm{mg} / \mathrm{L}$ of auxins. Among the tested compounds, treatment with $1 \mathrm{mg} / \mathrm{L}$ NAA resulted in the lowest accumulation of glucosinolates. Treatment with $0.1 \mathrm{mg} / \mathrm{L}$ IAA resulted in the accumulation of 2.2 times more glucosinolates than treatment with $1 \mathrm{mg} / \mathrm{L} \mathrm{NAA}$ and 1.6 times more glucosinolates than was found in control. Treatment with $0.1 \mathrm{mg} / \mathrm{L}$ IBA resulted in the second highest accumulation of glucosinolates. Our results suggest that auxin treatment, especially IAA at a concentration of $0.1 \mathrm{mg} / \mathrm{L}$ could be used to mass produce glucosinolates from hairy root culture of broccoli.
\end{abstract}

Key Words: Auxins, Broccoli, Glucosinolates, Hairy root.

\section{INTRODUCTION}

Brassicaceae (Cruciferae) is one of the 10 most economically important plant families and includes vegetables such as broccoli, brussels sprouts, cabbage, cauliflower, kale, radish and various mustards. Among the cultivated Brassicaceae, broccoli attracted attention after it was discovered that it contains high levels of isothiocyanate sulforaphane. Isothiocyanate sulforaphane, [4-(methylsulfinyl)butyl isothiocyanate], is produced from the breakdown of glucoraphanin, [4-(methylsulfinyl) butyl GSL] and has great potential anticarcinogenic properties. Sulforaphane is the most potent naturally occurring Phase II enzyme inducer and is considered to play an important role in the detoxification of xenobiotic compounds when assimilated with diet ${ }^{1,2}$.

Vegetables from the Brassicaceae family are among the most commonly grown vegetables worldwide. The family includes cabbage, broccoli, cauliflower, kale, collards and Brussels sprouts. Brassica vegetables are rich in bioactive compounds, including polyphenols, tocopherols, ascorbic acid, carotenoids and glucosinolates ${ }^{3-5}$. Epidemiological data have shown the ability of Brassica vegetables to lower the risk of cardiovascular diseases and several types of cancer, especially cancers of the gastrointestinal tract ${ }^{6}$. Additionally, the mortality of those who consume large quantities of Brassica vegetables is lower than that of persons with low consumption of fruits and vegetables ${ }^{7}$. These beneficial properties of Brassica vegetables are associated with the presence of bioactive compounds, which often have antioxidant and free radical scavenging properties. These compounds are also reported to affect gene expression, cell signaling and cell adhesion ${ }^{8}$.

Hairy root cultures have proven to be an efficient alternative system for the production of secondary metabolites in many plant species because of their genetic and biochemical stability, rapid growth rate and ability to synthesize natural compounds at levels comparable to whole plants ${ }^{9-11}$. A number of factors, including temperature, light, $\mathrm{pH}$, composition of the medium and exogenous treatment with plant growth regulators, affect the production of secondary metabolites in the hairy root cultures of various plants ${ }^{12}$. However, the influence of auxin treatment on glucosinolates production in $B$. oleracea var. italica hairy root culture has not yet been reported. In this 
paper, we describe the effects of auxins on the production of glucosinolates by hairy root cultures of B. oleracea var. italica that were transformed with Agrobacterium rhizogenes.

\section{EXPERIMENTAL}

(-)-Sinigrin (2-propenyl glucosinolate) hydrate from horseradish for use as an external standard and aryl sulfatase (Type H-1, EC 3.1.6.1) for desulfation of glucosinolates were purchased from Sigma-Aldrich (St. Louis, MO, USA). DEAESephadex A-25 for loading into a mini-column (1000 $\mu \mathrm{L}-\mathrm{Pas}-$ teur pipette) was provided by Amersham Biosciences (Uppsala, Sweden). HPLC-grade acetonitrile and methanol were supplied by J. T. Baker (Phillipsburg, NJ, USA). Ultrapure water having a resistivity of $18.2 \mathrm{MO} / \mathrm{cm}$ was produced by a PureLab Option from ELGA Labwater (Model LA 621, Marlow, UK).

Establishment of hairy root cultures: Young stems of Brassica oleracea var. italica were taken from plants grown in vitro and were cut at the ends into 7- mm sections. Excised stems were dipped into A. rhizogenes $\mathrm{R} 1000$ cultured in liquid inoculation medium for $10 \mathrm{~min}$, blotted dry on sterile filter paper and incubated in the dark at $25^{\circ} \mathrm{C}$ on agar-solidified MS medium ${ }^{13}$. After 2 days of co-cultivation, the explant tissues were transferred to a hormone-free medium containing MS salts and vitamins $(0.5 \mathrm{mg} / \mathrm{L}$ nicotinic acid, $0.5 \mathrm{mg} / \mathrm{L}$ pyridoxine- $\mathrm{HCl}, 0.1 \mathrm{mg} / \mathrm{L}$ thiamine- $\mathrm{HCl}$ and $2.0 \mathrm{mg} / \mathrm{L}$ glycine), $30 \mathrm{~g} / \mathrm{L}$ sucrose, $500 \mathrm{mg} / \mathrm{L}$ cefotaxime and $8 \mathrm{~g} / \mathrm{L}$ agar. Numerous hairy roots were observed emerging from the wound sites of explants within 2 weeks. The hairy roots were separated from the explant tissue and subcultured in the dark at $25^{\circ} \mathrm{C}$ on agar-solidified MS medium. After repeated transfer to fresh medium, rapidly growing hairy root cultures were obtained. Isolated roots $(0.5 \mathrm{~g} / \mathrm{L})$ were transferred to $30 \mathrm{~mL}$ of MS liquid medium, containing $30 \mathrm{~g} / \mathrm{L}$ sucrose, in $100 \mathrm{~mL}$ flasks. Root cultures were maintained at $25^{\circ} \mathrm{C}$ on a gyratory shaker $(100$ rev/min) in a growth chamber under standard cool white fluorescent tubes with a flux rate of $35 \mathrm{mmol} \mathrm{s}^{-1} \mathrm{~m}^{-2}$ and a $16 \mathrm{~h}$ photoperiod. After 30 days of culture, hairy roots were harvested. The dry weight and glucosinolate content of the hairy roots were determined. Three flasks were used for each culture condition and experiments were performed in duplicate.

Auxin treatment: Hairy roots of $B$. oleracea var. italica were allowed to grow for 3 weeks in half-strength MS medium supplemented with various concentrations of different auxins to study the effects on growth and glucosinolates production. Three different auxins (IAA, IBA and NAA) at 3 different concentrations $(0.1,0.5$ and $1 \mathrm{mg} / \mathrm{L})$ were used.

Extraction of desulfo-glucosinolates and HPLC analysis: Desulfo-glucosinolates were extracted using a slight modification of the procedures reported in a previous study ${ }^{14,15}$. Briefly, crude glucosinolates were extracted from $100 \mathrm{mg}$ of freezedried powder by boiling in $1.5 \mathrm{~mL}$ of $70 \%(\mathrm{v} / \mathrm{v}) \mathrm{MeOH}$ at $70{ }^{\circ} \mathrm{C}$ for 5 min using a water-bath. After centrifugation at $12,000 \mathrm{rpm}$ at $70{ }^{\circ} \mathrm{C}$ for $5 \mathrm{~min}$ in a Hanil microcentrifuge (MICRO 17R, Incheon, Korea), the supernatant was collected into a $5-\mathrm{mL}$ test tube and the residue was re-extracted twice as described above. The combined supernatants were taken as the crude glucosinolate extract. The extracts were loaded into a mini-column previously packed with DEAE-Sephadex A-
25 (40 mg dry weight) and desulfated by the addition of $75 \mu \mathrm{L}$ of an aryl sulfatase solution ( $23 \mathrm{mg} / \mathrm{mL})$. Desulfo-glucosinolates samples were elute $4 \mathrm{~d}$ into a $2-\mathrm{mL}$ microcentrifuge tube with $0.5 \mathrm{~mL}(\times 3)$ of ultrapure water.

The separation of desulfo-glucosinolates was carried out on a reversed-phase Inertsil ODS-3 column $(150 \times 3.0 \mathrm{~mm}$ i.d., particle size $3 \mu \mathrm{m}$; GL Sciences, Tokyo, Japan) with an E type cartridge guard column $(10 \times 2.0 \mathrm{~mm}$ i.d., $5 \mu \mathrm{m})$ using an Agilent Technologies 1200 series HPLC system (Palo Alto, CA, USA). The column oven temperature and the detection wavelength were set at $40{ }^{\circ} \mathrm{C}$ and $227 \mathrm{~nm}$, respectively and the flow rate was $0.2 \mathrm{~mL} / \mathrm{min}$. The mobile phase consisted of ultrapure water (solvent A) and $\mathrm{CH}_{3} \mathrm{CN}$ (solvent B). The gradient programs were as follows: a linear step from 7 to $24 \%$ of solvent B for 18 min, $24 \%$ of solvent B for the next 14 min, followed by a rapid drop to $7 \% \mathrm{~B}$ at $32.1 \mathrm{~min}$ and then isocratic conditions with $7 \% \mathrm{~B}$ for $8 \mathrm{~min}$ (total $40 \mathrm{~min}$ ). The individual glucosinolates were quantified according to their HPLC area and response factor by comparison to those of an external standard, $5 \mathrm{~mL}$ of sinigrin solution $(0.1 \mathrm{mg} /$ $\mathrm{mL}$ ), that was passed through the same extraction process (ISO 9167-1, 1992) $)^{15}$.

LC/ESI-MS analysis for quantitation of desulfoglucosinolates: The MS data were acquired by electrospray ionization (ESI)- mass spectrometry with an API 4000 Q TRAP system (Applied Biosystems, Foster City, CA, USA) in positive ion mode $\left([\mathrm{M}+\mathrm{H}]^{+}\right)$that was equipped with an Agilent 1200 series HPLC. The analytical conditions for mass spectrometry were as follows: scan range, $\mathrm{m} / \mathrm{z}$ 100- 800; scan time, $4.8 \mathrm{~s}$; curtain gas, 20 psi $\left(\mathrm{N}_{2}\right)$; heating gas temperature, $550{ }^{\circ} \mathrm{C}$; nebulizing gas, $50 \mathrm{psi}$; heating gas, $50 \mathrm{psi}$; ion spray voltage, $5500 \mathrm{~V}$; declustering potential, $100 \mathrm{~V}$; entrance potential, $10 \mathrm{~V}$.

\section{RESULTS AND DISCUSSION}

The growth rate of the hairy roots did not vary significantly between auxin treatments (Data not shown). HPLC and LC/ ESI-MS analysis of the hairy root cultures of broccoli identified 8 different glucosinolates, including glucoraphanin, gluconapin, 4-hydroxyglucobrassicin, glucoerucin, glucobrassicin, 4methoxyglucobrassicin, gluconasturtiin and neoglucobrassicin (Fig. 1). Total and individual glucosinolate levels varied significantly between auxin treatments (Table-1). In the hairy roots of broccoli, glucobrassi-cin, 4-methoxyglucobrassicin and neoglucobrassicin were the predominant glucosinolate.

For all auxins tested, treatment with $0.1 \mathrm{mg} / \mathrm{L}$ auxin resulted in greater accumulation of glucosinolates than higher concentrations and as the auxin concentration increased above this level, the accumulation of glucosinolates decreased (Table1). Treatment with $0.1 \mathrm{mg} / \mathrm{L}$ IAA resulted in the highest total accumulation of glucosinolates while treatment with 0.1 $\mathrm{mg} / \mathrm{L}$ IBA resulted in the second highest accumulation of glucosinolates and treatment with $1 \mathrm{mg} / \mathrm{L}$ NAA resulted in the lowest total accumulation of glucosinolates. Treatment with $0.1 \mathrm{mg} / \mathrm{L}$ IAA resulted in the accumulation of 2.2 times more glucosinolates than treatment with $1 \mathrm{mg} / \mathrm{L} \mathrm{NAA}$ and 1.6 times more glucosinolates than controls. Hairy roots treated with $0.1 \mathrm{mg} / \mathrm{L}$ IAA accumulated 4.7 times the amount of neoglucobrassicin, 2.5 times the amount of glucobrassicin and 


\begin{tabular}{|c|c|c|c|c|c|c|c|c|c|c|c|}
\hline No & Trivial name & Control & IAA 0.1 & IAA 0.5 & IAA 1.0 & IBA 0.1 & IBA 0.5 & IBA 1.0 & NAA 0.1 & NAA 0.5 & NAA 1.0 \\
\hline 1 & Glucoraphanin & $\begin{array}{c}0.78 \pm \\
0.82\end{array}$ & $\begin{array}{c}0.82 \pm \\
0.04\end{array}$ & $\begin{array}{c}1.09 \pm \\
0.07\end{array}$ & $\begin{array}{c}0.88 \pm \\
0.02\end{array}$ & $\begin{array}{c}0.91 \pm \\
0.01\end{array}$ & $\begin{array}{c}1.15 \pm \\
0.15\end{array}$ & $\begin{array}{c}1.06 \pm \\
0.04\end{array}$ & $\begin{array}{c}0.39 \pm \\
0.05\end{array}$ & $\begin{array}{c}0.98 \pm \\
0.09\end{array}$ & $\begin{array}{c}0.81 \pm \\
0.06\end{array}$ \\
\hline 2 & Gluconapin & $\begin{array}{c}0.51 \pm \\
0.15\end{array}$ & $\begin{array}{c}0.62 \pm \\
0.01\end{array}$ & $\begin{array}{c}0.54 \pm \\
0.06\end{array}$ & $\begin{array}{c}0.51 \pm \\
0.14\end{array}$ & $\begin{array}{c}0.57 \pm \\
0.02\end{array}$ & $\begin{array}{c}0.61 \pm \\
0.12\end{array}$ & $\begin{array}{c}0.49 \pm \\
0.00\end{array}$ & $\begin{array}{c}0.54 \pm \\
0.02\end{array}$ & $\begin{array}{c}0.41 \pm \\
0.00\end{array}$ & $\begin{array}{c}0.44 \pm \\
0.07\end{array}$ \\
\hline 3 & $\begin{array}{l}\text { 4-hydroxygluco } \\
\text { brassicin }\end{array}$ & $\begin{array}{c}0.19 \pm \\
0.04\end{array}$ & $\begin{array}{c}0.33 \pm \\
0.03\end{array}$ & $\begin{array}{c}0.24 \pm \\
0.00\end{array}$ & $\begin{array}{c}0.17 \pm \\
0.03\end{array}$ & $\begin{array}{c}0.26 \pm \\
0.03\end{array}$ & $\begin{array}{c}0.25 \pm \\
0.01\end{array}$ & $\begin{array}{c}0.30 \pm \\
0.02\end{array}$ & $\begin{array}{c}0.25 \pm \\
0.00\end{array}$ & $\begin{array}{c}0.23 \pm \\
0.06\end{array}$ & $\begin{array}{c}0.20 \pm \\
0.04\end{array}$ \\
\hline 4 & Glucoerucin & $\begin{array}{c}0.35 \pm \\
0.17\end{array}$ & $\begin{array}{c}0.66 \pm \\
0.10\end{array}$ & $\begin{array}{c}0.62 \pm \\
0.12\end{array}$ & $\begin{array}{c}0.49 \pm \\
0.17\end{array}$ & $\begin{array}{c}0.56 \pm \\
0.14\end{array}$ & $\begin{array}{c}0.72 \pm \\
0.08\end{array}$ & $\begin{array}{c}0.70 \pm \\
0.05\end{array}$ & $\begin{array}{c}0.64 \pm \\
0.05\end{array}$ & $\begin{array}{c}0.33 \pm \\
0.11\end{array}$ & $\begin{array}{c}0.32 \pm \\
0.16\end{array}$ \\
\hline 5 & Glucobrassicin & $\begin{array}{c}6.02 \pm \\
1.63\end{array}$ & $\begin{array}{c}11.50 \pm \\
0.48\end{array}$ & $\begin{array}{c}7.94 \pm \\
0.10\end{array}$ & $\begin{array}{c}5.02 \pm \\
1.20\end{array}$ & $\begin{array}{c}9.27 \pm \\
1.43\end{array}$ & $\begin{array}{c}6.37 \pm \\
1.06\end{array}$ & $\begin{array}{c}5.40 \pm \\
0.64\end{array}$ & $\begin{array}{c}5.67 \pm \\
0.33\end{array}$ & $\begin{array}{c}5.75 \pm \\
2.10\end{array}$ & $\begin{array}{c}4.64 \pm \\
1.75\end{array}$ \\
\hline 6 & $\begin{array}{l}\text { 4-methoxy } \\
\text { glucobrassicin }\end{array}$ & $\begin{array}{c}5.25 \pm \\
1.58\end{array}$ & $\begin{array}{c}8.35 \pm \\
0.98\end{array}$ & $\begin{array}{c}6.96 \pm \\
0.46\end{array}$ & $\begin{array}{c}4.75 \pm \\
1.13\end{array}$ & $\begin{array}{c}7.31 \pm \\
0.93\end{array}$ & $\begin{array}{l}5.99 \pm \\
0.25\end{array}$ & $\begin{array}{c}5.25 \pm \\
0.19\end{array}$ & $\begin{array}{c}6.13 \pm \\
0.16\end{array}$ & $\begin{array}{c}6.06 \pm \\
1.07\end{array}$ & $\begin{array}{c}4.33 \pm \\
1.11\end{array}$ \\
\hline 7 & Gluconasturtiin & $\begin{array}{c}0.96 \pm \\
0.38\end{array}$ & $\begin{array}{c}1.05 \pm \\
0.32\end{array}$ & $\begin{array}{c}1.59 \pm \\
0.37\end{array}$ & $\begin{array}{c}1.61 \pm \\
0.40\end{array}$ & $\begin{array}{c}1.36 \pm \\
0.06\end{array}$ & $\begin{array}{c}1.68 \pm \\
0.04\end{array}$ & $\begin{array}{c}1.22 \pm \\
0.66\end{array}$ & $\begin{array}{c}2.41 \pm \\
0.49\end{array}$ & $\begin{array}{c}0.87 \pm \\
0.09\end{array}$ & $\begin{array}{c}1.18 \pm \\
0.74\end{array}$ \\
\hline 8 & $\begin{array}{l}\text { Neogluco } \\
\text { brassicin }\end{array}$ & $\begin{array}{c}3.79 \pm \\
2.12 \\
\end{array}$ & $\begin{array}{c}4.68 \pm \\
1.24 \\
\end{array}$ & $\begin{array}{c}3.17 \pm \\
1.05 \\
\end{array}$ & $\begin{array}{c}1.91 \pm \\
1.07 \\
\end{array}$ & $\begin{array}{c}2.75 \pm \\
0.88 \\
\end{array}$ & $\begin{array}{c}2.28 \pm \\
0.40\end{array}$ & $\begin{array}{c}2.42 \pm \\
0.64\end{array}$ & $\begin{array}{c}4.00 \pm \\
0.02\end{array}$ & $\begin{array}{c}0.91 \pm \\
1.09 \\
\end{array}$ & $\begin{array}{c}1.00 \pm \\
0.53\end{array}$ \\
\hline Total & & $\begin{array}{c}17.86 \pm \\
6.33\end{array}$ & $\begin{array}{c}28.02 \pm \\
0.51\end{array}$ & $\begin{array}{c}22.14 \pm \\
0.24\end{array}$ & $\begin{array}{c}15.36 \pm \\
3.84\end{array}$ & $\begin{array}{c}23.00 \pm \\
3.36\end{array}$ & $\begin{array}{c}19.03 \pm \\
2.12\end{array}$ & $\begin{array}{c}16.85 \pm \\
2.11\end{array}$ & $\begin{array}{c}20.02 \pm \\
0.05\end{array}$ & $\begin{array}{c}15.55 \pm \\
4.03\end{array}$ & $\begin{array}{c}12.92 \pm \\
4.33\end{array}$ \\
\hline
\end{tabular}

1.93 times the amount of 4-methoxyglucobrassicin than those treated with $1 \mathrm{mg} / \mathrm{L}$ NAA (Table-1).

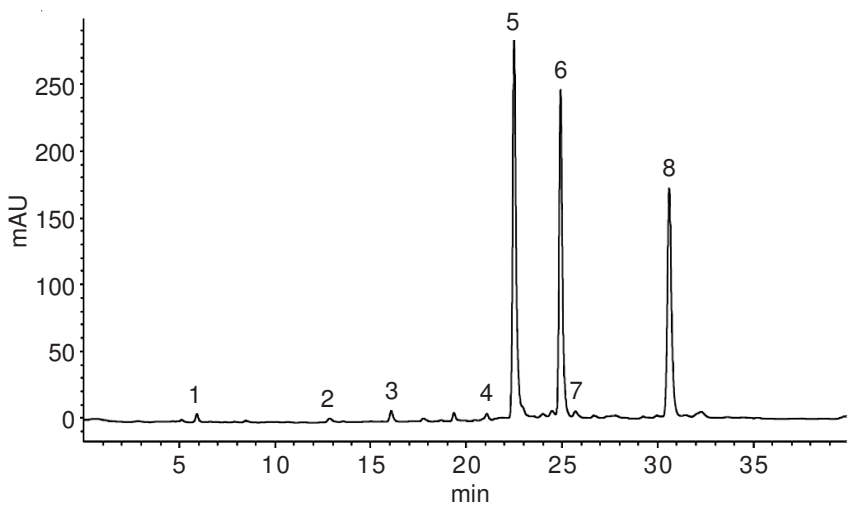

Fig. 1. HPLC chromatograms of glucosinolates in broccoli hairy root cultures

Secondary metabolite biosynthesis in transformed roots is largely controlled genetically but can be affected by nutritional and environmental factors. Auxins play important roles in plant growth and root development. The enhancement of hairy root growth and secondary metabolite concentration observed in this study is similar to the results of previous reports of enhanced growth and natural compound production after exogenous auxin treatments in hairy root cultures of Lippia dulcis $^{16}$, Lobelia inflata ${ }^{17}$, Panax hybrid ${ }^{18}$ and S. baicalensis ${ }^{19}$.

\section{Conclusion}

Our results indicate that hairy root culture is a valuable alternative approach for the production of glucosinolate compounds from broccoli and that auxin treatment, especially $0.1 \mathrm{mg} / \mathrm{L}$ IAA could be used for the mass production of glucosinolates. Our current laboratory efforts are aimed at further improving glucosinolate compound production in hairy root cultures of broccoli.

\section{REFERENCES}

1. J.W. Fahey, Y. Zhang and P. Talalay, Proc. Nat. Acad Sci USA, 94, 10367 (1997).

2. E.A.S. Rosa and A.S. Rodrigues, Hort. Sci., 36, 56 (2001).

3. A. Podsedek, Food Sci. Technol., 40, 1 (2007).

4. A.C. Kurilich, G.J. Tsau, A. Brown, L. Howard, B.P. Klein, E.H. Jeffery, M. Kushad, M.A. Wallig and J.A. Juvik, J. Agric. Food Chem., 47, 1576 (1999).

5. J. Nilsson, K. Olsson, G. Engqvist, J. Ekvall, M. Olsson, M. Nyman and B. kesson, J. Sci. Food Agric., 86, 528 (2006).

6. C.W.W. Beecher, Am. J. Clin. Nutr., 59, 1166 (1994).

7. A.Agudo, L. Cabrera, P. Amiano, E. Ardanaz, A. Barricarte, T. Berenguer, M.D. Chirlaque, M. Dorronsoro, P. Jakszyn, N. Larranaga, C. Martinez, C. Navarro, J.R. Quiros, M.J. Sanchez, M.J. Tormo and C.A. Gonzalez, Am. J. Clin. Nutr., 85, 1634 (2007).

8. P. Kroon and G. Williamson, J. Sci. Food Agric., 85, 1239 (2005).

9. M.C. Christey and R.H. Braun RH. Methods, Mol. Biol., 286, 47 (2005).

10. M.I. Georgiev, A.I. Pavlov and T. Bley, Appl. Microbiol. Biotechnol., 74, 1175 (2007).

11. S. Srivastava and A.K. Srivastava, Crit. Rev. Biotechnol., 27, 29 (2007).

12. F. Bourgaud, A. Gravot, S. Milesi and E. Gontier, Plant Sci., 161, 839 (2001).

13. T. Murashige and F. Skoog, Physiol. Plantarum, 15, 473 (1962).

14. S.J. Kim, C. Kawaharada, S. Jin, M. Hashimoto, G. Ishii and H. Yamauchi, Biosci. Biotechnol. Biochem., 71, 114 (2007).

15. International Organization of Standardization, ISO 9167-1:1992(E), Geneva, Switzerland (1992).

16. M. Sauerwein, T. Yamazaki and K. Shimomura, Plant Cell Rep., 9, 579 (1991).

17. I. Bálványos, L. Kursinszki and E. Szõke, Plant Growth Regul., 34, 339 (2001).

18. D. Washida, K. Shimomura, M. Takido and S. Kitanaka, Biol. Pharm. Bull., 27, 657 (2004).

19. Y.S. Kim, X. Li, W.T. Park, M.R. Uddin, N.I. Park, Y.B. Kim, M.Y. Lee and S.U. Park, Plant Omics J., 5, 24 (2012). 